\title{
Impact of Short-Term International Capital Flows on Interactivity of Stock Market and Real Estate Market in Chinese First-Tier Cities: A Viewpoint of "Co-Selling Effect"
}

\author{
Yiming Zhang \\ The Department of Finance, College of Economics, Jinan University, Guangzhou, China \\ Email:johninmen@hotmail.com
}

How to cite this paper: Zhang, Y. M. (2018). Impact of Short-Term International Capital Flows on Interactivity of Stock Market and Real Estate Market in Chinese First-Tier Cities: A Viewpoint of "Co-Selling Effect". Journal of Financial Risk Management, 7, 1-11.

https://doi.org/10.4236/jfrm.2018.71001

Received: December 18, 2017

Accepted: March 3, 2018

Published: March 6, 2018

Copyright $\odot 2018$ by author and Scientific Research Publishing Inc. This work is licensed under the Creative Commons Attribution International License (CC BY 4.0).

http://creativecommons.org/licenses/by/4.0/

\begin{abstract}
This paper offers a new prospect of interactivity of stock market and real estate market, it is found that not only the fundamental factors have impact on this, but the non-fundamental factors like short-term international capital flows play an important role in it. This paper tests the impact from short-term international capital flows on interactivity of stock market and real estate market by using dummy variables describing market conditions based on the "Co-Selling Effect" theory, the results show that the "Co-Selling Effect" does exist when market condition is bad, but this phenomenon could not be observed when market condition is good. This point is consistent with the classic theory.
\end{abstract}

\section{Keywords}

Co-Selling Effect, Short-Term International Capital Flows, Interactivity of Markets

\section{Introduction}

Since 2015, the word "the stock market disaster" can be seen in the media, this word refers to the event a sharp rising in stock market have been observed in the first half of 2015 with the downturn of the stock market in the last half of 2015. The Shanghai composite index which was hovering around three thousand points in early 2015, broke through the five thousand points in June 2015, the Shanghai composite index reached 5023.10, eye-catching Chinese stock market also attracted foreign capital inflow during this time, such as $\mathrm{ABU}$ dhabi invest- 
ment authority (ADIA) was formally approved to invest 1.5 billion dollars (about 9.2 billion yuan) in Chinese stock market, this number is more than $\$ 1$ billion last year. ADIA is the most powerful investment institution in the Middle East, its assets are spread around world. For common investors, buying QFII is a method for them to invest in Chinese market. According to the data from EPFR, by the May of 2015, mainly covering the QFII offshore China equity funds attracted more than $\$ 4$ billion in net inflows, this number is almost two times than the record in the second quarter of 2008. However, in the second half of 2015, China's stock market dropped to the nadir from a rare high in history in the early of 2016; the Shanghai composite index has dropped below three thousand points, the Shanghai composite index fell to 2949.60 points on January 2016. Only in less than a year, the Shanghai composite index shrank by $40 \%$. China's stock market was floundering in the first half of 2016, the Shanghai composite index climbed to three thousand points until the second half of 2016.

Along with the vibrating of stock market in recent period, China's real estate markets have appeared in the new situation which is different from the past time, according to the 70 largest cities housing price index issued by National Bureau of Statistics of the People's Republic of China, in the second half of 2014, house prices have fell in some cities, the housing prices of most large and medium-sized cities have fell below the level in the same period of 2013. In December of 2013, only one city in the 70 largest cities saw house price decline, and by the September of 2014, the number of cities with a year-on-year decline in prices had increased to 58 , but there were 10 cities which still saw a growing house price. Since the April of 2015, the real estate market has begun to appear in a completely different trend from the past, and the signs of recovery are gradually emerging.

By the April of 2016, there were 46 cities of the 70 largest cities which saw house price increasing according to the index issued by the national bureau of statistics, more than 40 in March. On average, price in 70 largest cities rose 4.2 per cent year on year, higher than 2.9 per cent in March. Starting from the second half of 2016, the heat of the real estate market began to cool, since October 2016, according to the 70 largest cities housing price index released by National Bureau of Statistics of the People's Republic of China, the year-on-year growth rate of first-tier cities real estate price fell significantly, housing price growth is not obvious, wandered around the zero, and even appeared negative growth in 2017.

After the housing supply system reform in 1998, China's real estate market began to move towards the marketization process. With the continuous development of the real estate market in China, on the one hand, this drives all kinds of funds come into the real estate market and pushing up the price of the real estate market (Wang, 2003). On the other hand, when properties have been taken into the investor's portfolio, which makes the real estate market price characteristics of fluctuation changed, and this makes the correlations between the real estate market and other markets become more obvious, it also leads the risk 
transmission form other markets to the real estate market. As one of the most important factors in the macroeconomic system in a country, the risk of the housing price should never be ignored. Therefore, the focus on the interactivity of the real estate market and other financial instruments are meaningful.

It's been a long time since the discussion of the correlation between the different markets; the past literatures mainly focus on three aspects as following: the long-term co-integration, the short-term causality and the common driving factors. Ambrose, Ancel, \& Griffths (1992) tested the co-integration relationship of American stock market and housing market, the test result showed the co-integration relationship exists in American stock market and housing market. Ling \& Naranjo (1999) argued that there are co-integration relationship in American REITs market and stock market which is without the share of the companies which run real estate business. Okunev, Wilson, \& Zurbrueg (2002) examined the data from Australian stock market and housing market, their results verified that a reciprocal Granger causality relation between Australian stock market and housing market. Quan \& Titman (1999) tested the correlation of the real estate price change and stock returns in 17 countries, the results showed that the short-term relationship in 16 countries is not obvious, but the correlation increased if a longer time span data were chosen. Based on the analysis method posed by Jorion \& Schwartz (1986), Liu, Hartzell, \& Greig (1990) tested the quarterly return datas of equity REITs, non-agricultural commercial real estate and the Standard \& Poor's 500 index, they think quarterly returns of equity REITs and the market portfolio have aco-integration relationship, but non-agricultural commercial real estate yields and the return on the market portfolio does not appear very obvious co-integration relationship, the main explanations of this phenomenon are the cost, quantity and quality of information. Quan \& Titman (1997) examined the correlation between stock market and real estate market in 17 countries and thought there existed a positive correlation between the stock market and real estate market from the total level, this positive relationship not only exists in the time range, but in the region range. Okunev, Wilson, \& Zurbruegg (2002) examined the correlation between the stock market and the real estate market in Australia during 1980 to 1999 , the results of the whole samples inspection show that in the stock market and real estate market in Australia, there existed a two-way granger causality relationship, the results also show that the structural changes have taken place during the period of samples, leading to only the one-way causal relationship existed which is from the stock market to the real estate market. Heaney \& Sriananthakumar (2012) analyzed the quarterly returns on stock market, REITs, direct investment in commercial real estate market and housing market in the period of 1986 and 2009 in Australia, the results support the views that taking real estate and stock into the investment portfolio has the effect of diversification.

Ba, Qin, \& Yuan (2009) used variable point inspection and measuring method of the linear and nonlinear Granger causality test to study the relationship between China's stock market and real estate market after the completion of the 
real estate market reform in 1998, the test result of interactive relationship showed the stock market is the housing market's linear Granger guide, and to a some extent, housing market is the stock market's hysteresis nonlinear Granger guide. Guo \& Zhang (2009) aimed to study the samples in Chinese eastern, central and western 35 largest cities in the period of the 2002-2006, using panel data model to study the relationship of nationwide real estate markets and stock markets for further study, their study showed that the real estate and stock markets are running in the current macroeconomic policy premise, jointly by the current rate of inflation, government revenues and expenditures, interest in the reserve requirement ratio and rediscount rate, the stock market and real estate has a positive relationship between the market price. Zhang \& Jiang (2014) argued that the interactive relationship of stock market and real estate market is influenced by the substitution effect, credit-price effect and the wealth effect, also influenced by GDP, interest rate, labor cost, price level, population age structure and so on.

Another typical view is that correlations between the house price and stock price depends on the fundamental forces of economic cycle, such viewpoint can be seen in the research of Quan \& Titman $(1997,1999)$, according to their research, when the economic cycle is in the boom phase, at this time the market liquidity is relatively abundant, all asset prices will rise, and when the economic cycle is in the doldrums, all asset prices are depressed by the macroeconomic factors. In contrast to the previous literature focusing on the macro fundamentals, this paper discusses the interactivity of the stock market and the real estate market from the point of view that non-fundamental factor like short-term international capital flows also play an important role in the interactivity of the stock market and the real estate market. In addition, previous studies have focused on discusses this problem from the point of views of macroscopic volume, but considering the long-standing imbalance regional development, the links of income and economic growth to foreign trade can be totally different, so the discussions on this problem from total level will lead to identification difficulties. This paper analyzes the mechanism of short-term international capital's influence on the interactivity of stock market and real estate market in Chinese first-tier cities which includes Beijing, Shanghai, Guangzhou and Shenzhen, which can overcome the identification difficulties.

\section{Hypothesis}

The real estate market reform in 1998 marked the beginning of China's real estate market marketization, investors attracted into the real estate market see the real estate assets as an important kind of categories in their portfolios, these capital provided liquidities to the real estate market, also marked the real estate market and other financial markets have fusion to some extent, an external financial market risk could spread into the real estate market.

From the point of the current research results, scholars analyzed the correla- 
tion between the stock market and real estate market from the perspective of fundamental factors such as economic climate condition, bank credit scale, the inflation, consumption, population age structure Quan \& Titman $(1997,1999)$. In fact, in addition to the fundamental factors, the interactivity of real estate and the stock market may also be affected by non-fundamental factors. That is, interactivity of the real estate and the stock market could change as the fundamental factors do not change because of the impact of non-fundamental factors.

Kyle \& Xiong (2000) established an equilibrium model for the analysis of intrinsic mechanism of financial markets "transmission" phenomena, when a market suffers negative impact, the wealth effect occurs, across-the-market investors tend to sell his position in the other markets to maintain liquidity, and across-the-market investors of the reaction could magnifies "infect" across different financial markets. This mechanism is also known as the "co-selling effect".

Short-term international capital flows could affect the correlation between different financial markets, as a barometer of economic conditions, the correlation of stock market and real estate market may also be affected by the short-term international capital. And the effect is even more pronounced when asset yields fall.

Therefore, this leads to two hypothesis of this paper as following:

Hypothesis 1: the real estate market in Chinese first-tier cities have financial characters, and as part of the financial markets, it could be correlated with the stock market, and this correlation is more obvious when the return on assets are in a low performance.

Hypothesis 2: short-term international capital with the features of high liquidity, high sensitivity and high profit-driven is the across-the-market investors, by "co-selling effect" mechanism, short-term international capital could affect the correlation of real estate market and stock market, and its impact is more obvious when the performance of the yield of assets reduce.

\section{Data}

\subsection{The Calculation of Interactivity of Markets}

This paper selected the Shanghai composite index closing price of the last trading day of each month as the representative of the stock market data, selected first-tier cities price index monthly data issued by State Statistics Bureau of China as representative of first-tier cities real estate market. From the Figure 1, it can be observed that the Shanghai composite index and the first-tier cities price index have the trend to move together to some extent. From this, take above data to calculate the logarithmic yield, and then standardize them, then use logarithm yield of the Shanghai composite index over the past six months and logarithmic growth rate of first-tier cities real estate price index to calculated rolling correlation coefficient, difference the rolling correlation coefficient for describing the changes of stock market and real estate market. 


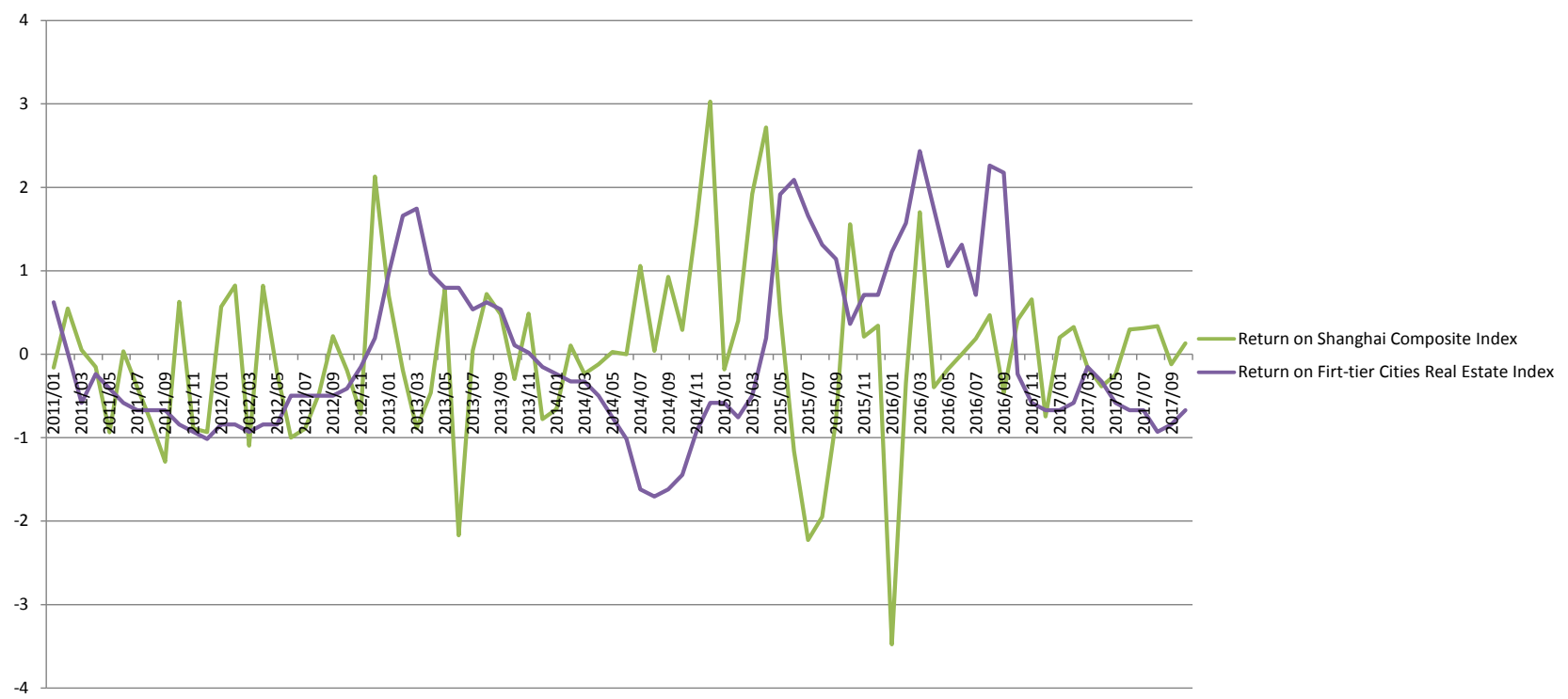

Figure 1. first-tier cities real estate price index (standardization) and Shanghai composite index (standardization) change trend.

\subsection{Calculation of Short-Term International Capital Flowing}

Monitoring the short-term international capital flows is very difficult currently, the estimating of short-term international capital flows can be roughly divided into indirect method and direct method (Zhang \& Xu, 2008), considering the availability of data and convenience, indirect method to estimate hot money is more popular in past papers. This paper also uses this method to estimate hot money, i.e. hot money = change in foreign exchange reserves - current account changes - foreign direct investment (FDI).

\section{Empirical Model}

To verify the hypothesis 1 of this paper, the dummy variable model is established as follows:

$$
\text { dcor }_{t}=c+\beta_{1} * r e r_{t}+\beta_{2} * s r_{t}+\beta_{3} * D_{1} * r e r_{t}+\beta_{4} * D_{2} * s r_{t}+\mu_{t}
$$

and

$$
\begin{gathered}
D_{1}= \begin{cases}0 & \text { rer }_{t}<\operatorname{average}(\text { rer }) \\
1 & \operatorname{rer}_{t}>\operatorname{average}(r e r)\end{cases} \\
D_{2}= \begin{cases}0 & s r_{t}<\operatorname{average}(s r) \\
1 & s r_{t}>\operatorname{average}(s r)\end{cases}
\end{gathered}
$$

For testing the influence of variables on the market at different market condition, two dummy variables $D_{1}$ and $D_{2}$ are added into the model and these dummy variables stand for the stock market condition and the first-tier cities real estate market condition. When $D_{1}=0$, it means the return on the first-tier cities market condition is at lower level, and the liquidity in the market is tense, so the first-tier cities market condition is bad at this time. When $D_{1}=1$, it means the return on the first-tier market is at higher level, and the liquidity in the market is 
rich, so the first-tier cities market condition is good at this time. When $D_{2}=0$, it means the return on the stock market condition is at lower level, and the liquidity in the market is tense, so the stock market condition is bad at this time. When $D_{2}=1$, it means the return on the stock market is at higher level, and the liquidity in the market is rich, so the stock market condition is good at this time. Average (rer) is the average of the rate of change of first-tier cities real estate price index, while average (sr) is the average of the Shanghai composite index. And the product of dummy variables and return on the assets are added into the model for testing whether the impact from the return on the interactivities of markets is different when the market condition is different. If $\beta_{1}$ was significant, then it could be proved that the return on the first-tier cities real estate market have influence on the interactivity of markets, and if $\beta_{3}$ was significant too, then it means the impact from return on the first-tier cities real estate market on the interactivity of markets is different when market condition is different. If $\beta_{2}$ was significant, then it could be proved that the return on the first-tier cities real estate market have influence on the interactivity of markets, and if $\beta_{4}$ was significant too, then it means the impact from return on the stock market on the interactivity of markets is different when market condition is different.

To verify the hypothesis 2 of this paper, based on the model in the hypothesis 1 , the dummy variable model is established as follows:

$$
\begin{aligned}
d c o r_{t}= & c+\alpha_{1} * r e r_{t}+\alpha_{2} * s r_{t}+\alpha_{3} * D_{1} * r e r_{t}+\alpha_{4} * D_{2} * s r_{t} \\
& +\alpha_{5} * s c f_{t}+\alpha_{6} * D_{1} * s c f_{t}+\alpha_{7} * D_{2} * D_{1} * s c f_{t}+\mu_{t}
\end{aligned}
$$

To testify the impact from short term international capital flows on the interactivities of markets, the variable $s c f_{t}$ and its product with dummy variables are added into the model. Especially, $D_{1} * s c f_{t}$ and $D_{2} * s c f_{t}$ are for describing the impact from the short term international capital flows on the interactivities of markets at different market condition. If $\alpha_{5}$ is significant, it is verified that the flow of short-term international capital affect the interactivity of the stock market and the real estate market whatever the market condition is. If $\alpha_{6}$ is significant, it indicates that impact from short-term international capital flows on interactivity is different when return on the first-tier cities real estate market is at different level, If $\alpha_{7}$ is significant, it indicates that impact from short-term international capital flows on interactivity is different when return on the stock market is at different level.

\section{Empirical Result}

Before the estimation of the model, the unit root test is applied to variables to ensure pseudo-regression does not exist. In this paper, Augmented Dickey-Fuller (ADF) test is used to test the existence of unit root, all of ADF test include interception term and determined by Schwarz Info Criterion, the maximum lags are 5. The result of ADF test is as following Table 1. 
Table 1. Test results of ADF.

\begin{tabular}{ccc}
\hline Variable & t-Statistic & P-value \\
\hline scf & -4.836193 & $0.0001^{* * *}$ \\
sr & -6.938527 & $0.0000^{* * *}$ \\
rer & -2.709591 & $0.0772^{*}$ \\
dcor & -9.100758 & $0.0000^{* * *}$ \\
\hline
\end{tabular}

$*, * *, * * *$ infer to the significant level $1 \%, 5 \%$ and $10 \%$ respectively.

From the test results, it can be seen that all variable used in the model pass the unit root test. So the procedure below can be continued.

\subsection{Market Conditions and Interactivity of Markets}

The inspection results of hypothesis 1 areas shown in the Table 2, from the significance of $\beta_{2}$ and $\beta_{4}$, it can be seen that the growth rate of Shanghai composite index do has impact on the interactivity of real estate market and stock market, and the impact is more obvious when asset yield is at lower level. A standardized unit drop of the Shanghai composite index will rise 0.1785 standardized units of interactivity of real estate market and stock market, namely, the lower the return on the stock market, the higher the degree of correlation between markets. The test results from Table 1 can be found that the coefficients of the product of the stock market dummy variable and the stock market yield are significant. And in contrast to the result when return on the stock market is at low level, the higher the return on the stock market is, the higher the degree of correlation between markets is when the return on the stock market in a higher level. In addition, the test result of hypothesis 1 show the yield of first-tier cities real estate market price index is not significant, and this feature is the same whatever first-tier cities real estate market price yield is at a higher level, or at a low level.

\subsection{Short-Term International Capital Flows and Interactivity of Markets}

The test result of hypothesis 2 are shown in Table 3, it can be found from Table 2 that the adding of short-term international capital flows improve the $R^{2}$-statistic and F-statistic remarkably, but the impact from growth rate of Shanghai composite index on the interactivity of real estate market and stock market do not have significant change. When the return on the stock market at a lower level, the higher the return on the stock market is, the lower the correlation of market is; When the stock market yields are at a higher level, the higher the yield of the stock market is, the higher the interactivity level of markets is, which is consistent with the test results of hypothesis 1 . From the test results of hypothesis 2 , it can be found that the influence of short-term international capital flows on the market is very significant, when the return on the stock market and real estate market are at lower level, the short-term international capital 
Table 2. Test results of hypothesis 1 .

\begin{tabular}{|c|c|c|}
\hline \multicolumn{3}{|c|}{ dcor } \\
\hline & Coefficient & $\mathrm{P}$-value \\
\hline Constant & -0.0941 & 0.3947 \\
\hline sr & -0.1785 & $0.0361^{* *}$ \\
\hline rer & 0.0182 & 0.8926 \\
\hline $\mathrm{D} 1{ }^{\star}$ rer & -0.1120 & 0.5753 \\
\hline $\mathrm{D} 2^{\star} \mathrm{sr}$ & 0.3753 & $0.0063^{\star * *}$ \\
\hline$R^{2}$-statistic & & \\
\hline F-statistic & & \\
\hline
\end{tabular}

Table 3. Test results of hypothesis 2 .

\begin{tabular}{|c|c|c|}
\hline \multicolumn{3}{|c|}{ dcor } \\
\hline & Coefficient & $\mathrm{P}$-value \\
\hline Constant & -0.0988 & 0.3554 \\
\hline $\mathrm{sr}$ & -0.1492 & $0.0692^{*}$ \\
\hline rer & 0.0455 & 0.7266 \\
\hline $\operatorname{scf}$ & -0.2270 & $0.0069^{* * *}$ \\
\hline $\mathrm{D} 1^{\star}$ rer & -0.1204 & 0.5316 \\
\hline $\mathrm{D} 2^{*} \mathrm{sr}$ & 0.3465 & $0.0089^{* * *}$ \\
\hline $\mathrm{D} 1^{*} \mathrm{scf}$ & 0.2233 & $0.0210^{* *}$ \\
\hline $\mathrm{D} 2{ }^{*} \mathrm{scf}$ & 0.1302 & 0.1863 \\
\hline$R^{2}$-statistic & & \\
\hline F-statistic & & \\
\hline
\end{tabular}

flows increase a standardized unit, standardization degree of correlation between market will drop 0.2270 units. It is important to note that when the return on the real estate market is at a higher level, standardization of short-term international capital flows levels increase one unit, the degree of correlation between market only reduce 0.0036 , so it can be observed that the power of impact from the short-term international capital flows is much more weak. And the product of the market state of the stock market and the short-term international capital flow is not significant.

\section{Conclusion}

This paper tests "Co-Selling Effect" between Chinese stock market and first-tier cities real estate market, the results show that "Co-Selling Effect" does exist in Chinese market, but the existence is with the condition that the assets yield is at lower level, the "Co-Selling Effect" for short-term international capital flows is obvious when the real estate market being at bad condition, but we can not ob- 
serve the same phenomenon in bad stock market condition.

One thing that needs to pay due attention is, when the market condition is good, "Co-Selling Effect" does not exist in both market, and the growth rate of Shanghai composite index even has a positive impact on the interactivity of markets.

This paper gives a new view for the interactivity of stock market and real estate market, we can see that not only the fundamental factors can influence the interactivity of stock market and real estate market, but the non-fundamental factors like short-term international capital flows also play an important role in it. So we can conclude that the risk aversion function could not be useful when the market condition is bad, and this point is very obvious when financial crisis happened like Russian bonds defaulted in 1998 and subprime crisis in 2007.

\section{References}

Ambrose, B. W., Ancel, E., \& Griffiths, M. D. (1992). The Fractal Structure of Real Estate Investment Trust Returns: The Search for Evidence of Market Segmentation and Nonlinear Dependency. Real Estate Economics, 20, 25-54.

https://doi.org/10.1111/1540-6229.00571

Ba, S. S., Qin, C. T., \& Zhu, Y. Q. (2009). Interaction between China Real Estate and Stock Market. Systems Engineering, No. 9, 16-21.

Guo, W. D., \& Zhang, H. (2009). Research on the Correlation between China's Stock Market and the Real Estate Market. Journal of Dongbei University of Finance and Economics, No. 2, 8-12.

Heaney, R., \& Sriananthakumar, S. (2012). Time-Varying Correlation between Stock Market Returns and Real Estate Returns. Journal of Empirical Finance, 19, 583-594. https://doi.org/10.1016/j.jempfin.2012.03.006

Jorion, P., \& Schwartz, E. (1986) Integration vs. Segmentation in the Canadian Stock Market. Journal of Finance, 41, 603-614. https://doi.org/10.1111/j.1540-6261.1986.tb04521.x

Kyle, A. S., \& Xiong, W. (2000). Contagion as a Wealth Effect of Financial Intermediaries. Social Science Electronic Publishing, 56, 1401-1440. https://doi.org/10.2139/ssrn.195030

Ling, D. C., \& Naranjo, A. (1999). The Integration of Commercial Real Estate Markets and Stock Markets. Real Estate Economics, 27, 483-515. https://doi.org/10.1111/1540-6229.00781

Liu, C. H., Hartzell, D. J., Greig, W., et al. (1990). The Integration of the Real Estate Market and the Stock Market: Some Preliminary Evidence. Journal of Real Estate Finance \& Economics, 3, 261-282. https://doi.org/10.1007/BF00216190

Okunev, J., Wilson, P., \& Zurbruegg, R. (2002). Relationships between Australian Real Estate and Stock Market Prices-A Case of Market Inefficiency. Journal of Forecasting, 21, 181-192. https://doi.org/10.1002/for.825

Quan, D. C., \& Titman, S. (1997). Commercial Real Estate Prices and Stock Market Returns: An International Analysis. Financial Analysts Journal, 53, 21-34.

https://doi.org/10.2469/faj.v53.n3.2082

Quan, D. C., \& Titman, S. (1999). Do Real Estate Prices and Stock Prices Move Together? An International Analysis. Real Estate Economics, 27, 183-207.

https://doi.org/10.1111/1540-6229.00771 
Wang, L. Y. (2003). The Impact and Prevention of International Speculative Capital on the Real Economy. Journal of Zhongnan University of Economics and Law, No.4, 71-73.

Zhang, C. S., \& Jiang, H. (2014). Research Review of the Relationship between Stock Market and Real Estate Market. Forward Position or Economics, No. 6, 147-157.

Zhang, M., \& Xu, Y. S. (2008). Gauge China's Current Hot Money Scale. Journal of Contemporary Asia-Pacific Studies, No. 4, 126-142. 